\title{
Hair Amino Acids: Normal Values and Results in Metabolic Errors
}

\author{
MARC VAN SANDE \\ From the Department of Neurochemistry, Born-Bunge Foundation, Berchem-Antwerp, Belgium
}

\begin{abstract}
van Sande, M. (1970). Archives of Disease in Childhood, 45, 678. Hair amino acids: normal values and results in metabolic errors. Hair amino acids have been studied in 10 controls and in 25 patients suffering from metabolic inborn errors. Abnormalities of hair amino acid pattern were found in several cases. In phenylketonuria ( 7 cases), the hair phenylalanine level was significantly higher than that of the normal subjects. Glutamic acid was decreased. In homocystinuria (5 cases), the phenylalanine level was increased. The results suggest that a detailed examination of the hair proteins could give further information.
\end{abstract}

Inborn errors of metabolism are often associated with morphological hair changes: for example, the imperfect hair pigmentation in phenylketonuria, the changes in hair texture in Hartnup's disease, the poorly pigmented brittle hair (trichorrhexis nodosa) in several cases of argininosuccinuria, and the sparse, blond, and brittle hair in homocystinuria. The reason for the associated hair abnormalities in these diseases is not always clear.

Relatively little is known concerning the amino acid composition of human hair, either in normal patients or in those with inborn errors. Most data in the literature report isolated findings in pathological cases comparing them with only few control cases. This excludes any statistical evaluation of the results.

The purpose of the present study was to establish normal values and to compare them with the results obtained in 25 patients suffering from metabolic errors.

\section{Material and Methods}

Hair specimens were obtained from 10 normal subjects: 9 children ( 2 boys and 7 girls aged from 4 to 12 years) and 1 adult (a woman of 20 years), and from 25 patients suffering from metabolic errors. Details are given in Table $I$.

The hair specimens were washed with distilled water, light petroleum (B.P. $60-80^{\circ} \mathrm{C}$.), absolute ethanol, and diethyl ether. Hydrolysis of $10 \mathrm{mg}$. samples in $6 \mathrm{~N} \mathrm{HC1}$ $\left(22\right.$ hours at $110^{\circ} \mathrm{C}$.) was carried out using the method of Moore and Stein (1963). The amino acid composition

Received 27 February 1970. of the hydrolysates was determined quantitatively on a Technicon Amino Acid Analyzer (column $140 \times 6 \mathrm{~mm}$., Chromobeads type A). The elution system was that described by Efron (1965). The values obtained for the labile amino acids are extrapolated to zero time, calculated on companion hydrolysates heated for 70 hours. The concentration of the amino acids is expressed as $\mathrm{g}$. nitrogen per $100 \mathrm{~g}$. nitrogen recovered from column, ammonia excluded.

\section{Results}

The mean values of the hair amino acids from the 10 control subjects and statistical data are given in Table II.

The results obtained on seven patients with phenylketonuria and five patients with homocystinuria have been statistically interpreted by means of the Student $t$ test for small samples. For the other cases, the level of an amino acid is considered abnormal when the value is outside the $95 \%$ confidence limit of the control group. The findings are represented graphically in the Fig. Only abnormal values are indicated.

In several hair specimens, abnormal values for some amino acids were obtained.

In the two cases of argininaemia, the microscopical appearance of the hair showed some similarities with the cases of sex-linked neurodegeneration described by Menkes et al. (1962): pili torti, trichorrhexis nodosa, and irregular variations in thickness; however, in our two patients these abnormalities were less pronounced. In the oldest patient Case 2, who had been on a low protein diet for several months, no abnormalities of the hair amino acid 
TABLE I

Details of Patients Studied

\begin{tabular}{|c|c|c|c|c|c|}
\hline Case No. & Sex & Age (yr.) & Diagnosis & Therapy & Hair colour \\
\hline 1 & $\mathbf{F}$ & $16 / 12$ & Hyperargininaemia & Low protein diet & Blond, dark \\
\hline 2 & $\mathrm{~F}$ & 5 & Hyperargininaemia & Low protein diet & Blond, white \\
\hline 3 & $\mathbf{F}$ & $12 / 12$ & Cystinosis & $\begin{array}{l}\text { Low methionine } \\
\text { and cystine diet }\end{array}$ & Blond, yellow \\
\hline 4 & $\mathbf{F}$ & 12 & Histidinaemia & None & Blond \\
\hline 5 & $\mathbf{M}$ & 59 & Histidinaemia & None & Blond, dark \\
\hline 6 & $\mathbf{F}$ & 2 & Glycinaemia without ketosis & None & Blond, dark \\
\hline 8 & $\mathrm{~F}$ & 4 & Argininosuccinuria & None & Blond, dark \\
\hline 9 & $\mathbf{F}$ & 5 & Argininosuccinuria & None & Blond, dark \\
\hline 10 & $\mathbf{F}$ & 3 & $\begin{array}{l}\text { Ammonia intoxication with ornithine carbamyl } \\
\text { transferase deficiency }\end{array}$ & Low protein diet & Blond, dark \\
\hline 11 & $\mathbf{M}$ & 5 & Homocystinuria & Pyridoxine & Blond, yellow \\
\hline 12 & $\mathbf{F}$ & 6 & Homocystinuria & Pyridoxine & Blond, yellow \\
\hline 13 & $\mathbf{F}$ & 7 & Homocystinuria & Pyridoxine & Blond, yellow \\
\hline 14 & $\mathbf{F}$ & 7 & Homocystinuria & Pyridoxine & Blond, yellow \\
\hline 15 & $\mathbf{F}$ & 25 & Homocystinuria & Pyridoxine & Blond, dark \\
\hline 17 & $\mathbf{M}$ & $8 / 12$ & Phenylketonuria & None & Blond, yellow \\
\hline 18 & $\mathbf{M}$ & 2 & Phenylketonuria & Diet & Blond, yellow \\
\hline 19 & $\mathbf{M}$ & 2 & Phenylketonuria & Diet & Blond, yellow \\
\hline 20 & $\mathbf{M}$ & 5 & Phenylketonuria & Diet & Blond, yellow \\
\hline 21 & $\mathbf{M}$ & 5 & Phenylketonuria & Diet & Blond, yellow \\
\hline 22 & $\mathbf{F}$ & 6 & Phenylketonuria & Diet & Blond, dark \\
\hline 23 & $\mathbf{M}$ & 16 & $\begin{array}{l}\text { Late infantile amaurotic idiocy (neuronal } \\
\text { ceroid lipofuscinosis) }\end{array}$ & None & Dark \\
\hline 24 & $\mathbf{F}$ & 11 & Monilethrix and mental retardation & None & Blond, white \\
\hline 25 & $\mathbf{M}$ & 3 & Trichorrhexis nodosa and mental retardation & None & Dark \\
\hline
\end{tabular}

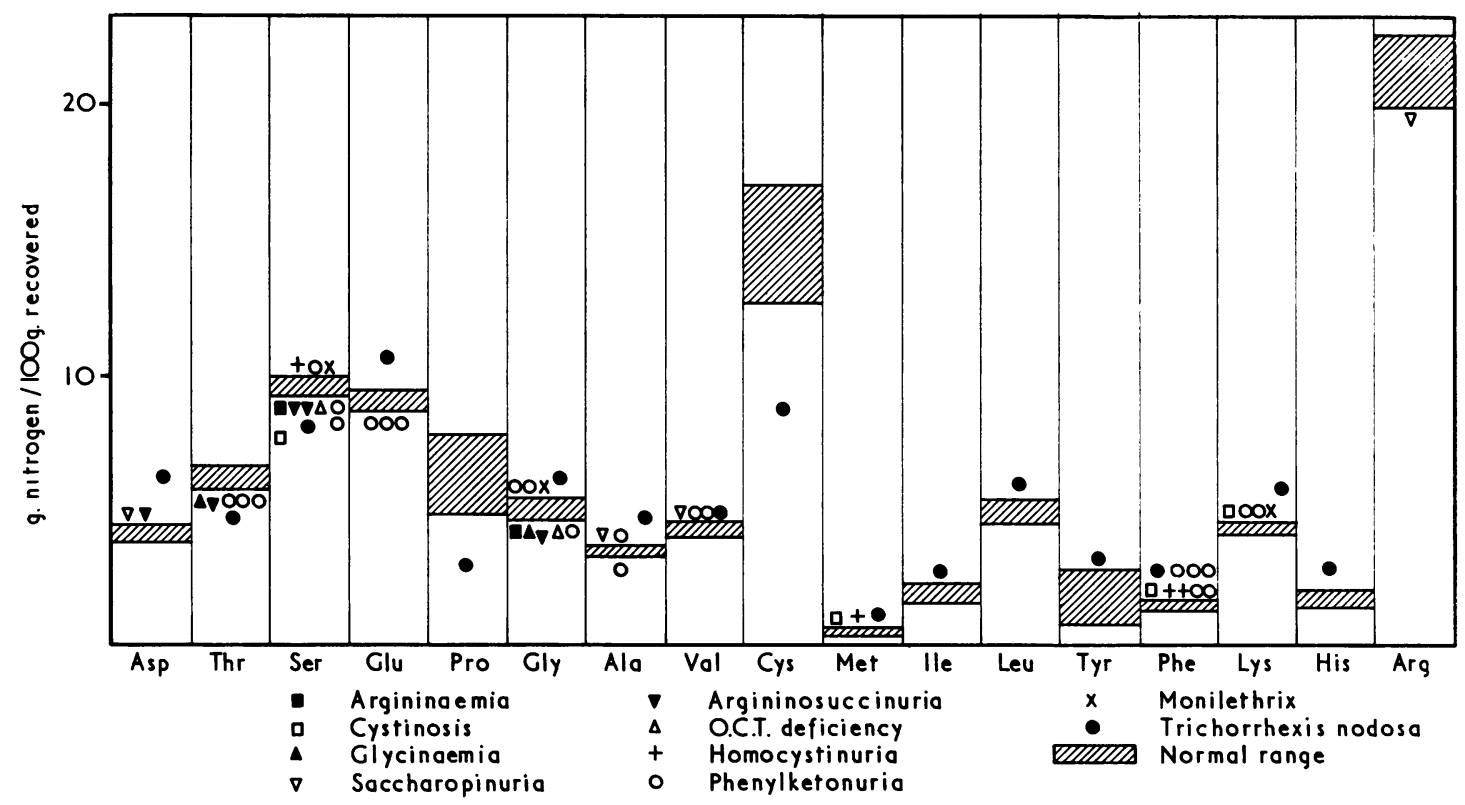

FIG.-Hair amino acids in metabolic errors. Only the values outside the normal range (mean $\pm 2 S D$ ) are indicated. 
composition were detected. In the sister (Case 1), who showed more pronounced biochemical abnormalities in the physiological fluids (Terheggen et al., 1969), hair serine and glycine levels were decreased. The hair arginine levels of the two patients were not altered.

In a case of cystinosis with rapid deterioration and fatal outcome, the hair cystine level was normal, though there were pronounced deposits of cystine crystals in the cornea and the bone-marrow.

In a case of non-ketotic hyperglycinaemia, the most striking finding was the lowered glycine level.

In saccharopinuria (Carson et al., 1968), aspartic acid, alanine, and valine were increased, while arginine was decreased.

In the two cases of argininosuccinuria, the only common anomaly was a decreased serine level. No argininosuccinic acid could be detected.

In a case of partial deficiency of ornithine carbamyl transferase activity and consequently

\section{TABLE II}

Hair Amino Acids of 10 Control Cases

\begin{tabular}{|c|c|c|c|c|}
\hline $\begin{array}{l}\text { Amno } \\
\text { Acid }\end{array}$ & Mean & SD & $\begin{array}{l}\text { SE of } \\
\text { Mean }\end{array}$ & $\begin{array}{c}\text { Range } \\
\text { Mean } \pm 2 \text { SD }\end{array}$ \\
\hline $\begin{array}{l}\text { Asp } \\
\text { Thr } \\
\text { Ser } \\
\text { Glu } \\
\text { Pro } \\
\text { Gly } \\
\text { Ala } \\
\text { Val } \\
\text { 1/2 Cys } \\
\text { Met } \\
\text { Ile } \\
\text { Leu } \\
\text { Tyr } \\
\text { Phe } \\
\text { Lys } \\
\text { His } \\
\text { Arg }\end{array}$ & $\begin{array}{r}4 \cdot 18 \\
6 \cdot 10 \\
9 \cdot 49 \\
9 \cdot 06 \\
6 \cdot 09 \\
5 \cdot 04 \\
3 \cdot 35 \\
4 \cdot 11 \\
14 \cdot 80 \\
0 \cdot 27 \\
1 \cdot 89 \\
4 \cdot 88 \\
1 \cdot 35 \\
1 \cdot 25 \\
4 \cdot 29 \\
2 \cdot 59 \\
21 \cdot 36\end{array}$ & $\begin{array}{l}0 \cdot 10 \\
0 \cdot 18 \\
0 \cdot 18 \\
0 \cdot 23 \\
0 \cdot 65 \\
0 \cdot 16 \\
0 \cdot 08 \\
0 \cdot 13 \\
1 \cdot 08 \\
0 \cdot 05 \\
0 \cdot 09 \\
0 \cdot 18 \\
0 \cdot 35 \\
0 \cdot 03 \\
0 \cdot 14 \\
0 \cdot 18 \\
0 \cdot 70\end{array}$ & $\begin{array}{l}0.13 \\
0.06 \\
0.06 \\
0.07 \\
0.24 \\
0.05 \\
0.03 \\
0.04 \\
0.34 \\
0.02 \\
0.03 \\
0.05 \\
0.11 \\
0.01 \\
0.04 \\
0.06 \\
0.22\end{array}$ & $\begin{array}{c}3 \cdot 98-4 \cdot 38 \\
5 \cdot 74-6 \cdot 46 \\
9 \cdot 13-9 \cdot 85 \\
8 \cdot 60-9 \cdot 52 \\
4 \cdot 79-7 \cdot 39 \\
4 \cdot 72-5 \cdot 36 \\
3 \cdot 19-3 \cdot 51 \\
3 \cdot 85-4 \cdot 37 \\
12 \cdot 64-16 \cdot 96 \\
0 \cdot 17-0 \cdot 37 \\
1 \cdot 71-2 \cdot 07 \\
4 \cdot 52-5 \cdot 24 \\
0 \cdot 63-2 \cdot 07 \\
1 \cdot 19-1 \cdot 31 \\
4 \cdot 01-4 \cdot 57 \\
2 \cdot 23-2 \cdot 95 \\
19 \cdot 96-22 \cdot 76\end{array}$ \\
\hline
\end{tabular}

$\star$ Results expressed as g. nitrogen per $100 \mathrm{~g}$. nitrogen recovered from column (ammonia excluded).

ammonia intoxication (Corbeel et al., 1969), threonine, serine, and glycine in the hair specimen were decreased. The biochemical abnormalities of the amino acids in the physiological fluids showed that the arginine level was lowered, and this was accompanied by high glutamic acid levels.

Only minor abnormalities were found in 5 hair specimens of homocystinuric patients. However, comparison of the mean values obtained for the control group with those of the 5 patients with homocystinuria shows an increase of the mean phenylalanine level in the hair of the patients $(0.01<p<0.02)$. The cystine levels were found to be normal.

In phenylketonuria, the most striking finding was the increased phenylalanine level in the hair amino acids in 5 cases out of 7 . In the 2 non-treated cases, this abnormality was accompanied by an increase of the lysine and glycine levels; threonine and glutamic acid were below the $95 \%$ confidence limit about the mean value of the control specimens. Statistical evaluation of the results on the 7 patients showed a decrease in the threonine level $(0.025<$ $\mathrm{p}<0.05)$ and in the glutamic acid concentration $(0.001<\mathrm{p}<0.005)$. Phenylalanine $(0.005<\mathrm{p}$ $<0.01)$ and lysine $(0.02<\mathrm{p}<0.025)$ were increased. On the patients on dietary therapy, a similar statistical study showed only a decreased glutamic acid level $(0.01<p<0.02)$, and an increased phenylalanine level $(0.025<\mathrm{p}<0.05)$. After treatment, the threonine levels become normal. No significant differences were found for the other amino acids.

The hair amino acid patterns of a patient with late infantile amaurotic idiocy and of two patients with histidinaemia were completely normal.

In a patient with monilethrix, associated with mental retardation (Sfaello and Hariga, 1967), serine, glycine, and lysine were increased.

The most abnormal pattern was obtained on a hair specimen, kindly sent us by Dr. Pollitt, of a patient with mental and physical retardation and trichorrhexis nodosa-the male sib of the family described by Pollitt, Jenner, and Davies (1968). Our results agreed well with those published by them.

\section{Discussion}

It could be suggested that excess of an amino acid in the biological fluids might result in the production of abnormal proteins. However, it has been shown that in the proteins of various phenylketonuric organs, no abnormalities in the pattern of amino acids could be detected (Block et al., 1940). Further evidence was given for haemoglobin by Allen and Schroeder (1957). These authors showed that the incorporation of phenylalanine into haemoglobin by a phenylketonuric subject was normal. On the other hand, it should be remembered that keratin is an unusual protein, the composition of which can be changed by dietary conditions, deficiency of trace metals, or a fault in lipid metabolism (Pollitt et al., 1968).

The results we obtained on the hair amino acid composition in metabolic errors are difficult to compare with the findings of other authors, as their 
number of control samples is too small to permit a statistical evaluation.

Vellan, Gjessing, and Seip (1969) described a normal pattern in two cases of cystinosis. The same authors did not mention any abnormality in a case of homocystinuria, except a relatively low cystine content. However, the value they mention for phenylalanine in this case is high, compared with the values of their two control cases.

The cystine levels of our 5 patients with homocystinuria were normal. As all these patients were treated with pyridoxine, the concentration of cystine may have been influenced by the therapy. Barber and Spaeth (1969) observed a low value for hair cystine in a patient before pyridoxine treatment which was drastically influenced by the treatment. Furthermore, hair pigmentation changed. However, keratinization may have been abnormal in other ways, in this patient, for the arginine values given by these authors are strikingly high before starting therapy.

Concerning phenylketonuria, our results are in opposition to those of Vellan et al. (1969), who reported no abnormality in the hair of an adult patient with this condition.

Though more patients need to be studied, we believe that our results indicate a biochemical relation between inborn errors and the frequently associated morphological hair abnormalities.

It is difficult to understand why in some of these diseases the very high concentration of one amino acid in the biological fluids is not mirrored in the hair keratin (e.g. argininaemia, histidinaemia), while in other diseases (e.g. phenylketonuria, glycinaemia) such a relation seems to exist.

Further evidence could be obtained by study of the hair proteins in these patients. The fractionation of hair keratin in high-sulphur, low-sulphur, and high-glycine proteins, further studied by the modern techniques of protein separation, could probably open a new field of investigation in the inborn errors.

I thank Professor Dr. A. Lowenthal for his advice and encouragement; Dr. K. Adriaenssens, Dr. N. A. J.
Carson, Dr. L. M. Corbeel, Dr. J. Dumon, Dr. J. Hariga, Dr. R. Humbel, Dr. R. Pollitt, Dr. $\mathbf{P}$. Schuurmans, Dr. H. G. Terheggen, and Dr. S. K. Wadman for providing hair samples from their patients; and Mr. J. Caers for expert technical assistance.

This study was supported by a grant of the 'Nationaal Fonds voor Geneeskundig Wetenschappelijk Onderzoek' and the 'Foundation van Hinderdael'.

\section{REFERENCES}

Allen, D. W., and Schroeder, W. A. (1957). A comparison of the phenylalanine content of hemoglobin of normal and phenylketonuric individuals : determination by ion exchange chromatography. Fournal of Clinical Investigation, 36, 1343.

Barber, G. W., and Spaeth, G. L. (1969). The successful treatment of homocystinuria with pyridoxine. Fournal of Pediatrics, 75, 463.

Block, R. J., Jervis, G. A., Bolling, D., and Webb, M. (1940). Chemical and metabolic studies on phenylalanine. III. The amino acid content of tissue protein of normal and phenylpyruvic oligophrenic individuals: a note on the estimation of phenylalanine. Fournal of Biological Chemistry, 134, 567.

Carson, N. A. J., Scally, B. G., Neill, D. W., and Carré, I. J. (1968). Saccharopinuria, a new inborn error of lysine metabolism. Nature (London), 218, 679.

Corbeel, L. M., Colombo, J. P., van Sande, M., and Weber, A. (1969). Periodic attacks of lethargy in a baby with ammonia intoxication due to a congenital defect of ureogenesis. Archives of Disease in Childhood, 44, 681.

Efron, M. L. (1965). Quantitative estimation of amino acids in physiological fluids using a Technicon amino acid analyzer. A modified technique with improved separation of the amino acids and a simplified method for preparation of blood samples. In Automation in Analytical Chemistry, p. 637, Mediad, New York.

Menkes, J. H., Alter, M., Steigleder, K. G., Weakley, D. R., and Sung, J. H. (1962). A sex-linked recessive disorder with retardation of growth, peculiar hair and focal cerebral and cerebellar degeneration. Pediatrics, 29, 764.

Moore, S., and Stein, W. H. (1963). Chromatographic determination of amino acids by the use of automatic recording equipment. In Methods in Enzymologv, vol. 6, p. 819. Ed. by S. P. Colowick, and N. O. Kaplan. Academic Press, New York.

Pollitt, R. J., Jenner, F. A., and Davies, M. (1968). Sibs with mental and physical retardation and trichorrhexis nodosa with abnormal amino acid composition of the hair. Archives of Disease in Childhood, 43, 211.

Sfaello, Z., and Hariga, J. (1967). Monilethrix associé à la débilité mentale: étude d'une famille. Archives Belges de Dermatologie et Syphiligraphie, 23, 363.

Terheggen, H. G., Schwenk, A., Lowenthal, A., van Sande, M., and Colombo, J. P. (1969). Argininaemia with arginase deficiency. Lancet, $2,748$.

Vellan, E. J., Gjessing, L. R., and Seip, M. (1969). Hair amino acids in cystinosis, homocystinuria, Fölling's disease and tyrosinosis. Acta Faediatrica Scandinavica, 58, 287.

Correspondence to Dr. Marc van Sande, Department of Neurochemistry, Born-Bunge Stichting, F. Williotstraat, 2600-Berchem, Belgium. 